Key Words:

Melt Rate, SB5, DWPF, glass

Retention:

Permanent

\title{
SLUDGE BATCH 5 SLURRY FED MELT RATE FURNACE TESTS WITH FRITS 418 AND 550
}

\author{
D. H. Miller
}

B. R. Pickenheim

\section{DECEMBER 2008}

Savannah River National Laboratory Savannah River Nuclear Solutions Aiken, SC 29808 


\section{DISCLAIMER}

This work was prepared under an agreement with and funded by the U.S. Government. Neither the U. S. Government or its employees, nor any of its contractors, subcontractors or their employees, makes any express or implied:

1. warranty or assumes any legal liability for the accuracy, completeness, or for the use or results of such use of any information, product, or process disclosed; or

2. representation that such use or results of such use would not infringe privately owned rights; or

3. endorsement or recommendation of any specifically identified commercial product, process, or service.

Any views and opinions of authors expressed in this work do not necessarily state or reflect those of the United States Government, or its contractors, or subcontractors.

Printed in the United States of America

Prepared for

U.S. Department of Energy 
Key Words:

Melt Rate, SB5, DWPF, glass

Retention:

Permanent

\title{
SLUDGE BATCH 5 SLURRY FED MELT RATE FURNACE TESTS WITH FRITS 418 AND 550
}

\author{
D. H. Miller
}

B. R. Pickenheim

\section{DECEMBER 2008}

Savannah River National Laboratory

Savannah River Nuclear Solutions

Savannah River Site

Aiken, SC 29808 


\section{REVIEWS AND APPROVALS}

D. H. Miller, Author, Process Engineering Technology

Date

B. R. Pickenheim, Co-Author, Process Engineering Technology

Date

D. K. Peeler, Technical Reviewer, Process Engineering Technology

Date

C. C. Herman, Manager, Process Engineering Technology

Date

S. L. Marra, Acting Manager,

Date

Environmental \& Chemical Process Technology Research Programs

J. E. Occhipinti, Manager

Date

Waste Solidification Engineering

- ii - 


\section{TABLE OF CONTENTS}

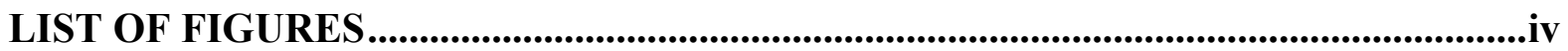

LIST OF TABLES............................................................................................................................iv

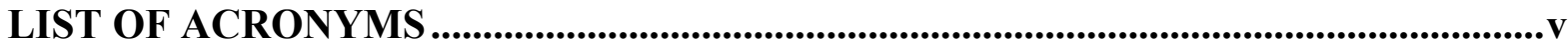

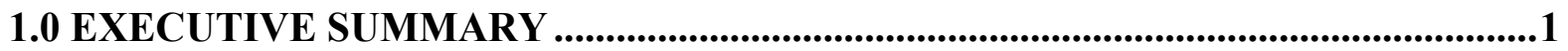

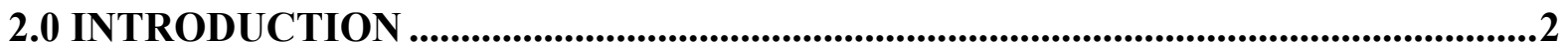

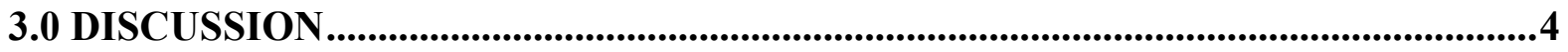

3.1 22-L SRAT/SME Feed Preparation details for SMRF runs ...........................................

3.2 SB5 SMRF Run ....................................................................................................................5

3.3 Analytical Results......................................................................................................................6

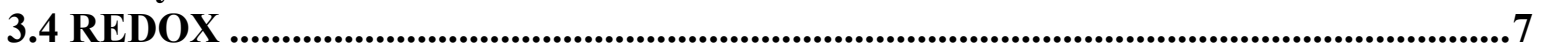

3.5 Power Consumption ......................................................................................................................

3.6 Melt Rate ...........................................................................................................................

3.7 MRF Results .........................................................................................................................8

4.0 SUMMARY AND PATH FORWARD ........................................................................10

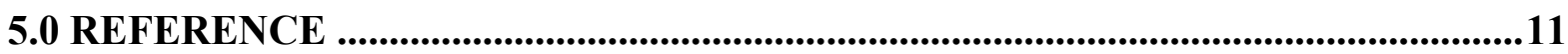

APPENDIX A. Acid Calculations ........................................................................................12

APPENDIX B. SMRF Glass Analysis (wt\% Oxide)...............................................................18

APPENDIX C. SMRF REDOX Results ........................................................................19

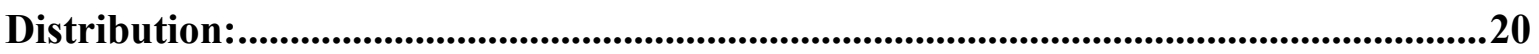




\section{LIST OF FIGURES}

Figure 1. SB5 - Frit 418 9

Figure 2. SB5 - Frit 550 .9

\section{LIST OF TABLES}

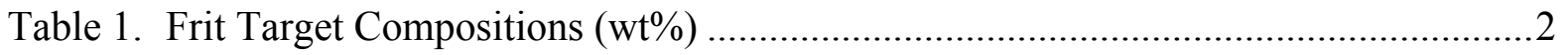

Table 2. SB5 SME Product Data ...............................................................................

Table 3. SMRF Glass Sample Identification ................................................................. 6

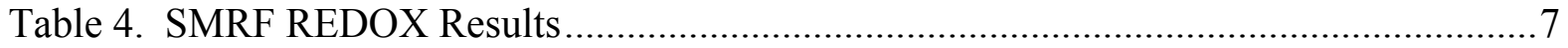

Table 5. Power (BTU/Min) Consumptions for the SB5 SMRF Runs ................................ 7

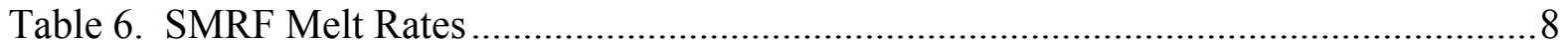

Table 7. MRF Melt Rates ........................................................................................ 8 


\section{LIST OF ACRONYMS}

$\begin{array}{ll}\text { ACTL } & \text { Aiken County Technology Laboratory } \\ \text { DWPF } & \text { Defense Waste Processing Facility } \\ \text { MRF } & \text { Melt Rate Furnace } \\ \text { PSAL } & \text { Process Science Analytical Laboratory } \\ \text { REDOX } & \text { REDuction/OXidation } \\ \text { SB4 } & \text { Sludge Batch 4 } \\ \text { SB5 } & \text { Sludge Batch 5 } \\ \text { SME } & \text { Slurry Mix Evaporator } \\ \text { SMRF } & \text { Slurry Fed Melt Rate Furnace } \\ \text { SRAT } & \text { Sludge Receipt and Adjustment Tank } \\ \text { SRNL } & \text { Savannah River National Laboratory } \\ \text { WL } & \text { Waste Loading }\end{array}$




\subsection{EXECUTIVE SUMMARY}

Based on Melt Rate Furnace (MRF) testing for the Sludge Batch 5 (SB5) projected composition and assessments of the potential frits with reasonable operating windows, the Savannah River National Laboratory (SRNL) recommended Slurry Fed Melt Rate Furnace (SMRF) testing with Frits 418 and 550. DWPF is currently using Frit 418 with SB5 based on SRNL's recommendation due to its ability to accommodate significant sodium variation in the sludge composition. However, experience with high boron containing frits in DWPF indicated a potential advantage for Frit 550 might exist. Therefore, SRNL performed SMRF testing to assess Frit 550's potential advantages.

The results of SMRF testing with SB5 simulant indicate that there is no appreciable difference in melt rate between Frit 418 and Frit 550 at a targeted 34 weight \% waste loading. Both batches exhibited comparable behavior when delivered through the feed tube by the peristaltic pump. Limited observation of the cold cap during both runs showed no indication of major cold cap mounding.

MRF testing, performed after the SMRF runs due to time constraints, with the same two Slurry Mix Evaporator (SME) dried products led to the same conclusion. Although visual observations of the cross-sectioned MRF beakers indicated differences in the appearance of the two systems, the measured melt rates were both $\sim 0.6 \mathrm{in} / \mathrm{hr}$. Therefore, SRNL does not recommend a change from Frit 418 for the initial SB5 processing in DWPF.

Once the actual SB5 composition is known and revised projections of SB5 after the neptunium stream addition and any decants is provided, SRNL will perform an additional compositional window assessment with Frit 418. If requested, SRNL can also include other potential frits in this assessment should processing of SB5 with Frit 418 result in less than desirable melter throughput in DWPF. The frits would then be subjected to melt rate testing at SRNL to determine any potential advantages. 


\subsection{INTRODUCTION}

The Defense Waste Processing Facility (DWPF) began processing of Sludge Batch 5 (SB5) in December 2008. In support of flowsheet development efforts for SB5, the Savannah River National Laboratory (SRNL) recommended Frit 418 for initial processing ${ }^{1}$. The Frit 418 recommendation was primarily based on its robustness to potential sludge composition variation. At that time, there was uncertainty in several factors in the Tank Farm and in DWPF processing that ultimately would dictate the nominal composition of SB5. These uncertainties included the mass of SB4 remaining in Tank 40 at the time of the Tank 51 transfer, additions of caustic to Tank 40 (SB4) due to anticipated decants, the degree of Aldissolution in Tank 51, and the final wash end point. One of the primary oxides being tracked with these uncertainties was the $\mathrm{Na}_{2} \mathrm{O}$ concentration given it has a significant impact on several process or product performance properties. Given these uncertainties and the need to order a frit to support initial operations (to avoid a feed outage), SRNL performed a series of paper study assessments which identified the ability of Frit 418 to provide relatively large operating windows for a large compositional range of SB5. That being the case, Frit 418 was recommended with the knowledge that DWPF may be giving up optimization (with respect to melt rate) for robustness to ensure Slurry Mix Evaporator (SME) acceptability evaluations would be successful.

After the initial recommendation, SRNL continued to evaluate alternative frits that might improve melt rate while maintaining acceptable operating windows. Based on Melt Rate Furnace (MRF) data, Miller et al. ${ }^{2}$ identified Frit 550 as a leading candidate to improve melt rate while maintaining relatively large operating windows (Frit 550 is similar to the Frit 540 actually used in the initial MRF testing). Slurry-Fed Melt Rate Furnace (SMRF) tests with Frit 418 and Frit 550 were recommended to assess whether Frit 550 would lead to a higher melt rate relative to Frit 418. If so, DWPF could elect to transition from Frit 418 to Frit 550 after ordering, fabrication, and receipt of this alternative frit. The target compositions of the two frits are given in Table 1.

Table 1. Frit Target Compositions (wt\%)

\begin{tabular}{||c|c|c|c|c||}
\hline FRIT & $\mathbf{B}_{\mathbf{2}} \mathbf{O}_{\mathbf{3}}$ & $\mathbf{L i}_{\mathbf{2}} \mathbf{O}$ & $\mathbf{N a}_{\mathbf{2}} \mathbf{O}$ & $\mathbf{S i O}_{\mathbf{2}}$ \\
\hline 418 & 8 & 8 & 8 & 76 \\
\hline 550 & 12 & 8 & 7 & 73 \\
\hline
\end{tabular}

Miller et al. ${ }^{3}$ provided a high level summary of the SMRF results to support frit procurement efforts for initial processing. This report provides a detailed discussion of the feed preparation, SMRF testing and feeding conditions, measured feed and pour rates, and observed cold cap behavior. The SB5 SMRF testing was conducted to gain insight into the feeding behavior of the SB5 system that cannot be obtained in the dry fed MRF. 
This work is being performed under the auspices of the Technical Task Request HLWDWPF-TTR-2007-0007 and supporting Task Technical \& Quality Assurance Plan ${ }^{5}$. 
SRNL-STI-2008-00508, REVISION 0

\subsection{DISCUSSION}

\subsection{2-L SRAT/SME FEED PREPARATION DETAILS FOR SMRF RUNS}

The SB5 sludge composition used in these melt rate tests was designated as "SB5-C". This sludge was designed to simulate the composition of Tank 40 after blending ( $30 \%$ Tank 51 / $70 \%$ Tank 40). The details regarding the preparation of this simulant have been previously reported. ${ }^{6}$ As is common when making large batches for melter studies, no mercury or noble metals were added during the SRAT/SME process.

The Sludge Receipt and Adjustment Tank/Slurry Mix Evaporator (SRAT/SME) products were made in the Aiken County Technology Laboratory (ACTL) in 22 L vessels using the sludge composition referenced above. The feed preparation process strategy used $130 \%$ acid stoichiometry and targets of $45 \%$ total solids, 34 weight \% waste loading (WL) and 0.2 REDOX defined as $\mathrm{Fe}^{2+} / \Sigma \mathrm{Fe}$. Further details on the run parameters are documented in the SRAT/SME R\&D Directions. ${ }^{7}$ A typical acid calculation is provided in Appendix A. Waste loading calculations using lithium values from the glass pour samples indicate that the Frit 550 run is $>3 \%$ higher than the Frit 418 run. When additional frit and SRAT components are brought into the calculations, the difference is reduced to $<1 \%$; with the average being $35.6 \%$ and $34.8 \%$ respectively for Frit 550 and Frit 418 . An estimate using the two SME products indicates WL values of $33.7 \%$ and $33.4 \%$ for frit runs 550 and 418 . Both of these calculations yield results that are within normal variation associated with waste loading. With the limited number of samples and the sensitivity of calculations to the lithium analysis, it is believed that waste loading did not play a significant role in the results.

The change in frit composition is most evident in the increase in B with the SB5/Frit 550 composition. The final $\mathrm{pH}$ was much lower than typical flowsheet runs because no noble metals are used in the feed preparation. In the absence of noble metals, less formate is destroyed so the product remains more acidic. Neither $\mathrm{pH}$ nor offgas data was collected during these runs as is the current practice for melter feed preparation.

Table 2 gives the measured composition and physical properties of the SME Products. Two $22 \mathrm{~L}$ runs were performed and blended to make each SMRF feed listed in the table. 
Table 2. SB5 SME Product Data

\begin{tabular}{|c|c|c|c|c|c|}
\hline $\begin{array}{l}\text { Element (wt\% } \\
\text { calcined solids) }\end{array}$ & $\begin{array}{l}\text { SB5/ } \\
\text { Frit } 418 \\
\end{array}$ & $\begin{array}{l}\text { SB5/ } \\
\text { Frit 550 }\end{array}$ & Anion (mg/kg) & $\begin{array}{l}\text { SB5/ } \\
\text { Frit } 418 \\
\end{array}$ & $\begin{array}{l}\text { SB5/ } \\
\text { Frit 550 }\end{array}$ \\
\hline $\mathrm{Al}$ & 4.33 & 4.30 & $\mathrm{~F}$ & $<100$ & $<100$ \\
\hline $\mathrm{B}$ & 1.59 & 2.45 & $\mathrm{Cl}$ & $<100$ & $<100$ \\
\hline $\mathrm{Ba}$ & 0.011 & $<0.010$ & $\mathrm{NO}_{2}$ & $<100$ & $<100$ \\
\hline $\mathrm{Ca}$ & 0.561 & 0.557 & $\mathrm{NO}_{3}$ & 48000 & 48800 \\
\hline $\mathrm{Cr}$ & 0.016 & 0.017 & $\mathrm{PO}_{4}$ & $<100$ & $<100$ \\
\hline $\mathrm{Cu}$ & $<0.010$ & $<0.010$ & $\mathrm{C}_{2} \mathrm{O}_{4}$ & $<100$ & $<100$ \\
\hline $\mathrm{Fe}$ & 7.57 & 7.68 & $\mathrm{HCO}_{2}$ & 104000 & 106000 \\
\hline $\mathrm{K}$ & 0.089 & 0.066 & & & \\
\hline $\mathrm{Li}$ & 2.30 & 2.55 & Solids (wt\%) & & \\
\hline $\mathrm{Mg}$ & 0.365 & 0.357 & Total & 45.2 & 45.2 \\
\hline $\mathrm{Mn}$ & 1.75 & 1.82 & Insoluble & 34.9 & 34.6 \\
\hline $\mathrm{Na}$ & 9.62 & 9.61 & Soluble & 10.3 & 10.6 \\
\hline $\mathrm{Ni}$ & 0.867 & 0.89 & Calcined & 36.6 & 36.7 \\
\hline $\mathrm{P}$ & $<0.100$ & $<0.100$ & & & \\
\hline $\mathrm{Pb}$ & $<0.010$ & $<0.010$ & Final pH & 4.71 & 4.71 \\
\hline $\mathrm{S}$ & 0.059 & 0.056 & & & \\
\hline $\mathrm{Si}$ & 23.9 & 23.6 & Density (g/ml) & 1.34 & 1.34 \\
\hline $\mathrm{Sr}$ & $<0.010$ & $<0.010$ & & & \\
\hline $\mathrm{Ti}$ & 0.045 & $<0.010$ & & & \\
\hline $\mathrm{Zn}$ & 0.012 & $<0.010$ & & & \\
\hline $\mathrm{Zr}$ & 0.098 & 0.011 & & & \\
\hline
\end{tabular}

\subsection{SB5 SMRF RUN}

Details of the SMRF configuration are documented in previous reports ${ }^{8}$. The operational parameters for the SMRF tests were consistent with previous testing and are outlined in the test plan ${ }^{9}$. The melt pool and vapor space set points were $1125^{\circ} \mathrm{C}$ and $750^{\circ} \mathrm{C}$, respectively. The vapor space temperature controller was clamped at $87 \%$ output as in previous runs. Prior to starting the test, a sample of both SME products was run through the feed system. Both yielded acceptable flow rates based on previous pump parameters. A check of the solids content verified that both batches hit the target of $45 \mathrm{wt} \%$ total solids.

The SMRF was charged with $6 \mathrm{Kg}$ of glass (drained from the SMRF after the July 07 SB4Frit 418/510 run). The SMRF was heated to set point on 10/27/08. Melt pool depth was measured at 3 " before the addition of $1 \mathrm{Kg}$ startup glass.

Feeding of SB5/Frit 418 SME product began on 10/28/08 at approximately 0700 hours. The agitator speed was $180 \mathrm{rpm}$ and the feed pump motor was operated at $261 \mathrm{rpm}$. This setting yielded a feed cycle of 110-115 grams per 20 seconds. Feeding and pouring continued until 
$\sim 1530$ hours with only a few interruptions for feed tube plugging. These were short in duration and were corrected by reversing the material flow direction in the feed supply line for several seconds, until slurry was forced back into the feed tank. The cold cap was observed on several occasions for evidence of overfeeding, such as excessive mounding or a completely dark surface. In general, the area under the feed tube was dark, but there were areas around the edge of the cold cap that were thin and an orange glow could be observed. The cold cap level was consistently located below the over flow cap located on the pour tube. Based on round sheet data being taken at the time, the amount of glass being poured matched well with the expected quantity based on the feed rate and measured calcine solids $(36.7$ $\mathrm{wt} \%)$.

Feeding of SB5/Frit 550 SME product began on 10/29/08 at approximately 0700 hours using the same agitator and pump settings. These settings yielded a feed cycle of approximately 110 grams per 20 seconds. Feeding and pouring continued until $\sim 1530$ hours with only a few stoppages for feed tube plugging. These were similar in duration to the Frit 418 run and were quickly corrected. The cold cap was observed on several occasions and no indication of overfeeding was observed. During the test run the cold cap appeared to be $\sim 1$ " higher than the Frit 418 run, but never reached the top of the pour tube cap. This could be an indication of a slightly higher foaming tendency with Frit 550, but did not cause any problems in the processing. A similar pattern was observed in subsequent MRF testing and will be discussed in Section 3.7. As with the Frit 418 batch, the amount of glass being poured matched well with the expected quantity.

\subsection{ANALYTICAL RESULTS}

Several pour stream glass samples were taken throughout the two SMRF runs. Table 3 shows the sample ID and description of the samples that were submitted to the Process Science Analytical Laboratory (PSAL) for analysis. The results of the analyses are shown in Appendix B. As expected, the boron content steadily increased throughout the run as the Frit 550 material displaced the Frit 418 glass in the melter. The silica content also decreased slightly throughout the run, which is consistent with the lower $\mathrm{SiO}_{2}$ content in Frit 550 . Samples chosen to represent the two end products yielded results that indicated both runs had similar waste loadings as discussed in section 3.1.

Table 3. SMRF Glass Sample Identification

\begin{tabular}{||l|l|l|l|l|c||}
\hline \hline Sample ID & Lab ID & Date & Time & Description & Test ID \\
\hline & & & & & \\
\hline SMRF 0234 & $08-2290$ & $10 / 28$ & $15: 35$ & After 7200 grams of glass poured & SB5/Frit 418 \\
\hline SMRF 0236 & $08-2291$ & $10 / 29$ & $9: 45$ & After 1830 grams of glass poured & SB5/Frit 550 \\
\hline SMRF 0237 & $08-2292$ & $10 / 29$ & $15: 45$ & After 6600 grams of glass poured & SB5/Frit 550 \\
\hline SMRF 0238 & $08-2293$ & $10 / 30$ & $8: 20$ & End of drain & \\
\hline
\end{tabular}




\subsection{REDOX}

Previous studies have shown that melt rate results can be affected by the REDOX conditions during feed preparation. Completely oxidized feeds can mask the results obtained in melt rate testing. A sample of both SME batches was converted to glass using the closed crucible procedure to assess the final REDOX of the glass. The glass was then submitted to the PSAL for REDOX $\left(\mathrm{Fe}^{2+} / \Sigma \mathrm{Fe}\right)$ determination. Table 4 summarizes the REDOX values of the glass samples and the complete data set is found in Appendix C. As seen from the data, the two SME batches showed similar REDOX results, and both were near the normal range (target values are generally from 0.15 to 0.20 ). Based on these results, there is no reason to suspect that REDOX conditions were a major influence on the melt rate findings.

Table 4. SMRF REDOX Results

\begin{tabular}{|c|c|c||}
\hline Sample ID & Frit & $\begin{array}{c}* \text { REDOX } \\
\left(\text { Fe2 }+/ \sum \text { Fe }\right)\end{array}$ \\
\hline Blend 19/20 & 418 & 0.143 \\
\hline Blend 21/22 & 550 & 0.146 \\
\hline
\end{tabular}

* Average of two measurements from each of three samples

\subsection{POWER CONSUMPTION}

Power consumption for the plenum and melt pool heaters were monitored for both runs. The amps are recorded every 30 minutes to verify that the furnace elements were properly functioning during the testing. Table 5 gives the total power used for the two SB5 SMRF tests as well as the power consumed in a previous SB4/Frit 418 (45\% total solids) SMRF test $^{10}$.

Table 5. Power (BTU/Min) Consumptions for the SB5 SMRF Runs

\begin{tabular}{||c|c|c|c||}
\hline \hline Power Zone & SB5/Frit 418 & SB5/Frit 550 & SB4/Frit 418 \\
\hline Plenum & & & \\
\hline Melt Pool & 96.7 & 95.3 & 94.2 \\
\hline
\end{tabular}

Both SMRF runs had plenum power requirements that were similar and in line with previous testing. The vapor space temperature is the controlling variable in SMRF testing since it is used to initiate the feed cycle. The vapor space thermocouple is located $\sim 5$ " below the top of the melter along with an over-temperature thermocouple. In the past, major differences in 
power consumption were assumed to be related to the influence of different cold cap properties and the presence of "shine" from the melt pool. It is possible that the slightly higher foam layer or the small difference in frit composition contributed to the increased melt pool power requirement for Frit 550, but the difference was not visually obvious. Melt pool temperatures remained constant at $1125^{\circ} \mathrm{C}$ during both tests.

\subsection{MELT RATE}

Table 6 shows the melt rate calculated from feed rate, and actual melt rates over a six hour period beginning at 0900 for each frit. This time was chosen to allow the system to stabilize for $\sim 2$ hours after initiation of feeding. The calculated melt rate is determined by multiplying the measured feed rate by the calcine factor. The melt rate for Frit 550 was slightly lower than that for Frit 418, but not by a significant amount. The values are slightly different than those reported in the previous high level memo ${ }^{3}$ because a different time period was used after viewing the data graphs to ensure steady state conditions.

Table 6. SMRF Melt Rates

\begin{tabular}{||c|c|c|c||}
\hline \hline Frit & $\begin{array}{c}\text { Average } \\
\text { Feed Rate } \\
\text { (g/min) }\end{array}$ & $\begin{array}{c}\text { Calculated } \\
\text { Melt Rate } \\
\text { (g/min) }\end{array}$ & $\begin{array}{c}\text { Actual } \\
\text { Melt Rate } \\
(\mathbf{g} / \mathbf{m i n})\end{array}$ \\
\hline 418 & & & 13.7 \\
\hline 550 & 38.1 & 13.9 & 13.3 \\
\hline
\end{tabular}

\subsection{MRF RESULTS}

Due to time constraints and frit availability, Frit 550 was not run in the MRF prior to the two SMRF runs covered in this report. A MRF run using SME product from the SMRF testing was completed on 11/31/08, along with a Frit 418 standard. The melt rate results from the MRF are shown in Table 7 below.

Table 7. MRF Melt Rates

\begin{tabular}{||c|c|c|c|c||}
\hline \hline Sample ID & Frit & $\begin{array}{c}\text { Target } \\
\text { Waste } \\
\text { Loading (\%) }\end{array}$ & $\begin{array}{c}\text { SME Product } \\
\text { ID }\end{array}$ & $\begin{array}{c}\text { Melt } \\
\text { Rate } \\
\text { (In/Min) }\end{array}$ \\
\hline MRF 08-077 & 418 & 34 & $08-S B 5-19 / 20$ & 0.62 \\
\hline MRF 08-078 & 550 & 34 & $08-S B 5-21 / 22$ & 0.58 \\
\hline Frit Std 1st layer & 418 & N/A & N/A & 1.71 \\
\hline Frit Std 2nd layer & 418 & N/A & N/A & 3.21 \\
\hline
\end{tabular}


As found with the SMRF testing, the MRF results indicate little difference in melt rate between the two frits, with Frit 418 being slightly faster than Frit 550. Figures 1 and 2 show a cross section of both MRF test beakers. Although the measured melt rates (based on the amount of glass produced) were similar, there is a significant difference in the visual observations of the cross-sections. The upper crown visible in the Frit 418 beaker (Figure 1) was several inches higher in the Frit 550 beaker and did not contain as many large bubbles. The crown portion of the Frit 550 run remained in the upper portion of the beaker that was cut away prior to sectioning. The amount of glass left in the bottom of both beakers was very similar, which accounts for the reported melt rates being similar.

Figure 1. SB5 - Frit 418

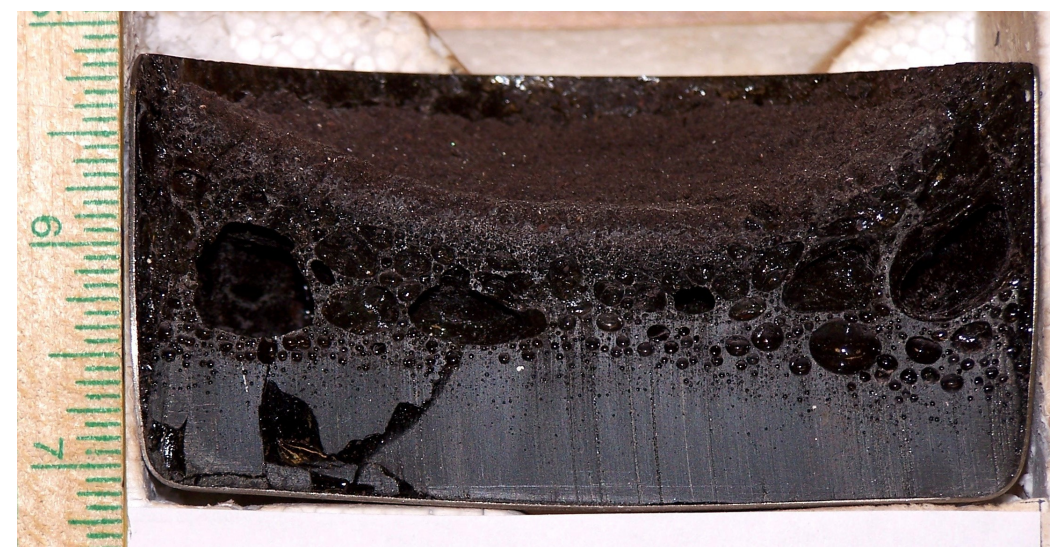

Figure 2. SB5 - Frit 550

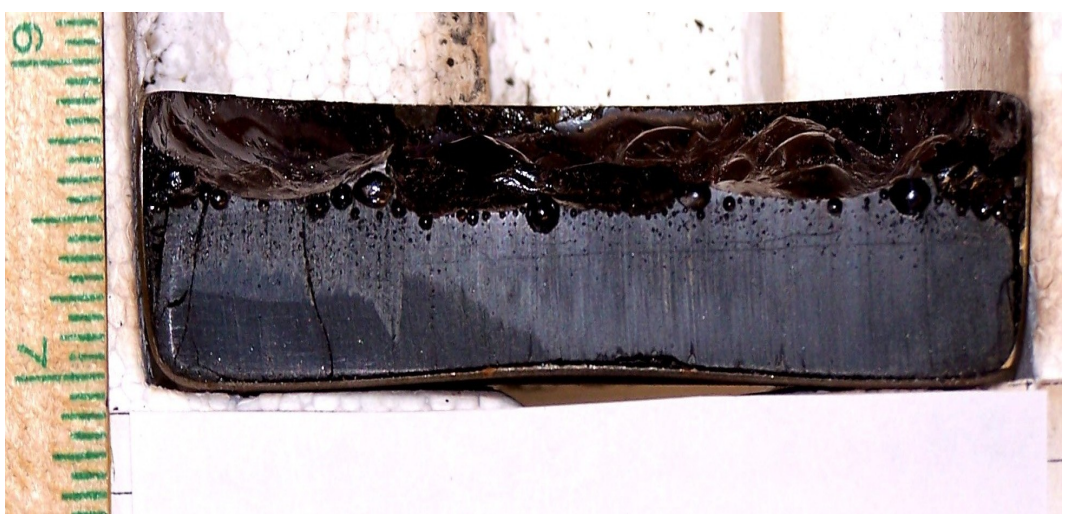

Previous SB5 MRF tests suggested that increasing the boron concentration in the frit had positive impacts on melt rate for the SB5 system. That being said, the SRMF and MRF results are somewhat surprising given the $\mathrm{B}_{2} \mathrm{O}_{3}$ concentrations of Frit 550 and Frit 418 of 12 wt $\%$ and 8 wt $\%$, respectively. However, Frit 550 does have 1 wt $\%$ less $\mathrm{Na}_{2} \mathrm{O}$ than Frit 418 , which may have offset the potential or assumed advantage of the higher $\mathrm{B}_{2} \mathrm{O}_{3}$ concentration. 


\subsection{SUMMARY AND PATH FORWARD}

The results of SMRF testing with SB5 indicate that there is no appreciable difference in melt rate between Frit 418 and Frit 550. The average pour rates for the Frit 418 and Frit 550 systems were 13.7 and 13.3 grams of glass per minute, respectively. Both batches exhibited comparable behavior in the feed system and processed smoothly without a large number of interruptions. Limited observation of the cold cap during both runs showed similar patterns with no indication of major cold cap mounding. Subsequent MRF testing with the same two SME products led to the same conclusion. Although there were differences in the appearance of the MRF beakers, the measured melt rates were both $\sim 0.6 \mathrm{in} / \mathrm{hr}$.

Coupling the melt rate information with recent Measurement Acceptability Region (MAR) assessments for SB5 pre- and post-nitrite and Np additions ${ }^{11}$ SRNL recommends that DWPF utilize Frit 418 to process SB5 without transitioning to Frit 550. Given the potential differences in waste loading indicated by lithium analyses, additional MRF testing could be conducted to better define the impact of waste loading on melt rate in the current SB5/Frit 550 system. Once an actual SB5 composition is obtained from the Tank $403 \mathrm{~L}$ sample, revised projections of SB5 after the neptunium stream addition and any decants should be assessed. As part of the neptunium qualification efforts, SRNL will perform an additional MAR assessment with Frit 418. If requested, SRNL could also include other potential frits in this assessment should processing of SB5 with Frit 418 result in less than desirable melter throughput in DWPF. The frits could then be subjected to melt rate testing at SRNL to determine any potential advantages. 


\subsection{REFERENCE}

${ }^{1}$ K. M. Fox, Recommended Frit Composition for Initial Sludge Batch 5 Processing at the Defense Waste Processing Facility, WSRC-STI-2008-00338, June 2008, Savannah River National Laboratory, Aiken, South Carolina.

${ }^{2}$ D. H. Miller, K. M. Fox, B. R. Pickenheim, M. E. Stone, Melt Rate Furnace Testing for Sludge Batch 5 Frit Selection, SRNS-STI-2008-00092, September 2008, Savannah River National Laboratory, Aiken, South Carolina.

${ }^{3}$ D. H. Miller, T. M. Jones, B. R. Pickenheim, Sludge Batch 5 Slurry-Fed Melt Rate Furnace (SMRF) Results for Frit 418 and Frit 550, SRNL-L3100-2008-00102, November 2008, Savannah River National Laboratory, Aiken, South Carolina.

${ }^{4}$ B. H. Culbertson, Sludge Batch 5 Frit Optimization, HLW-DWPF-TTR-2007-0007, Washington Savannah River Company, Aiken, South Carolina.

${ }^{5}$ D. K. Peeler, Sludge Batch 5 Frit Optimization, WSRC-STI-2006-00321, Washington Savannah River Company, Aiken, South Carolina.

${ }^{6}$ D. P. Lambert, M. E. Stone, B. R. Pickenheim, D. R. Best, D. C. Koopman, Sludge Batch 5 Simulant Flowsheet Studies, SRNS-STI-2008-00024, October 2008, Savannah River National Laboratory, Aiken, South Carolina.

${ }^{7}$ B. R. Pickenheim, 22-L SRAT Runs for Melt Rate Testing: SB5-19 - SB5-22, SRNLL3100-2008-00075, October 2008, Savannah River National Laboratory, Aiken, South Carolina.

${ }^{8}$ M.E. Smith, D. H. Miller and T. M. Jones, SMRF and MRF DWPF Melt Rate Testing for SB2/SB3 (Case 6b-250 Canisters), WSRC-TR-2003-00466, Westinghouse Savannah River Company, Aiken, South Carolina.

${ }^{9}$ D. H. Miller, Slurry-Fed Melt Rate Furnace Run Plan with Frits 418 and 550, SRNLL3100-2008-00052, October 2008, Savannah River National Laboratory, Aiken, South Carolina.

${ }^{10}$ M.E. Smith, T. M. Jones, D. H. Miller, Sludge Batch 4 Baseline Melt Rate Furnace and Slurry-Fed Melt Rate Furnace Tests with Frits 418 and 510, WSRC STI-2007-00450, Savannah River National Laboratory, Aiken, South Carolina.

${ }^{11}$ K. M. Fox, T. B. Edwards, D. K. Peeler, The Impact of Np and Sodium Nitrite Additions on the Projected Operating Windows for Sludge Batch 5, SRNL-L3100-200800103, Savannah River National Laboratory, Aiken, South Carolina. 


\section{APPENDIX A. Acid Calculation}


SRNL-STI-2008-00508, REVISION A

\begin{tabular}{|c|c|c|}
\hline SRNL SRAT Acid, Trim Chemical, Dewater and Redox Calc Revised: & $6 / 1 / 2007$ & \\
\hline \multicolumn{3}{|l|}{ Run Description: } \\
\hline Run \# & SB5-19 & \\
\hline Sludge Feed Batch \# & SB5-C carboy 1 & \\
\hline SRAT Vessel Volume, $\mathrm{L}$ & 22 & \\
\hline \multicolumn{3}{|l|}{ Calculation Notes: } \\
\hline 1. To calculate an acid mix to achieve a REDOX target, click on macro. & $\begin{array}{l}\text { RedOx } \\
\text { Target } \\
\text { Macro } \\
\end{array}$ & Redox at target \\
\hline 2. To Calculate the oxalate in the trimmed sludge, click on macro. & $\gg \quad \begin{array}{l}\text { Oxalate } \\
\text { Target }\end{array}$ & Sludge Oxalate at target \\
\hline \multicolumn{3}{|l|}{ Warnings } \\
\hline \multicolumn{3}{|l|}{ No Mercury Warning, No Coal Warning, No Oxalate Warning } \\
\hline Table 1 -- Sludge Analyses for Acid Calculations, Batch \# & SB5-C carboy 1 & \\
\hline Fresh Sludge Mass without trim chemicals & $16,758.9$ & g slurry \\
\hline Fresh Sludge Weight $\%$ Total Solids & 12.50 & $\mathrm{wt} \%$ \\
\hline Fresh Sludge Weight \% Calcined Solids & 9.51 & wt $\%$ \\
\hline Fresh Sludge Weight \% Insoluble Solids & 7.85 & wt $\%$ \\
\hline Fresh Sludge Density & 1.090 & $\mathrm{~kg} / \mathrm{L}$ slurry \\
\hline Fresh Sludge Nitrite & 6,175 & $\mathrm{mg} / \mathrm{kg}$ slurry \\
\hline Fresh Sludge Nitrate & 3,940 & $\mathrm{mg} / \mathrm{kg}$ slurry \\
\hline Fresh Sludge Oxalate & 0 & $\mathrm{mg} / \mathrm{kg}$ slurry \\
\hline Fresh Sludge Formate & 0 & $\mathrm{mg} / \mathrm{kg}$ slurry \\
\hline Fresh Sludge Coal/Carbon source & 0.000 & wt $\%$ dry basis \\
\hline Fresh Sludge Manganese (\% of Calcined Solids) & 5.050 & wt $\%$ calcined basis \\
\hline Fresh Sludge Slurry TIC (treated as Carbonate) & 1,338 & $\mathrm{mg} / \mathrm{kg}$ slurry \\
\hline Fresh Sludge Hydroxide (Base Equivalents) $\mathrm{pH}=7$ & 0.632 & Equiv Moles Base/L slurry \\
\hline Fresh Sludge Mercury (\% of Total Solids in untrimmed sludge) & 0.0000 & $\mathrm{wt} \%$ dry basis \\
\hline Fresh Sludge Supernate manganese & 0 & $\mathrm{mg} / \mathrm{L}$ supernate \\
\hline Fresh Sludge Supernate density & 1.024 & $\mathrm{~kg} / \mathrm{L}$ supernate \\
\hline Table 2 -- SRAT Processing Assumptions, Run \# & SB5-19 & \\
\hline Conversion of Nitrite to Nitrate in SRAT Cycle & 20.00 & $\mathrm{gmol} \mathrm{NO}_{3}{ }^{-} / 100 \mathrm{gmol} \mathrm{NO}_{2}^{-}$ \\
\hline Destruction of Nitrite in SRAT and SME cycle & 100.00 & $\%$ of starting nitrite destroyed \\
\hline Destruction of Formic acid charged in SRAT & 15.00 & $\%$ formate converted to $\mathrm{CO}_{2}$ etc. \\
\hline Destruction of oxalate charged & 50.00 & $\%$ of total oxalate destroyed \\
\hline Percent Acid in Excess Stoichiometric Ratio & 130.00 & $\%$ \\
\hline SRAT Product Target Solids & 25.00 & $\%$ \\
\hline Nitric Acid Molarity & 10.340 & Molar \\
\hline Formic Acid Molarity & 23.600 & Molar \\
\hline DWPF Nitric Acid addition Rate & 2.0 & gallons per minute \\
\hline DWPF Formic Acid addition Rate & 2.0 & gallons per minute \\
\hline REDOX Target & 0.200 & $\mathrm{Fe}^{+2} / / \mathrm{Fe}$ \\
\hline REDOX Equation $\left(7\right.$ for $\mathrm{Mn}^{+7}$, otherwise assumes $\mathrm{Mn}^{+4}$ ) & 7 & Enter 7 for newest redox equation \\
\hline Trimmed Sludge Target Ag metal content & 0.00000 & total $\mathrm{wt} \%$ dry basis after trim \\
\hline Trimmed Sludge Target wt $\% \mathrm{Hg}$ dry basis & 0.00000 & total $\mathrm{wt} \%$ dry basis after trim \\
\hline Trimmed Sludge Target Pd metal content & 0.00000 & total $\mathrm{wt} \%$ dry basis after trim \\
\hline Trimmed Sludge Target Rh metal content & 0.00000 & total $\mathrm{wt} \%$ dry basis after trim \\
\hline Trimmed Sludge Target Ru metal content & 0.00000 & total $\mathrm{wt} \%$ dry basis after trim \\
\hline Trimmed Sludge Target $\mathrm{Wt} \%$ Coal/carbon source dry basis & 0.00 & total $\mathrm{wt} \%$ dry basis after trim \\
\hline Trimmed Sludge Target oxalate after trim (wt \% not mg/kg) & 0.000 & total $\mathrm{wt} \%$ dry basis after trim \\
\hline Water to dilute fresh sludge and/or rinse trim chemicals & 0.000 & $\mathrm{~g}$ \\
\hline Total Water added to flush both the Nitric and Formic Acid Lines & 50.0 & $\mathrm{~g}$ \\
\hline Sample Mass of Trimmed sludge (SRAT Receipt sample, if any) & 0.0 & $\mathrm{~g}$ \\
\hline Mass of SRAT cycle samples & 0.000 & $\mathrm{~g}$ \\
\hline $\mathrm{Wt} \%$ Active Agent In Antifoam Solution & 10 & $\%$ \\
\hline Basis Antifoam Addition for SRAT (generally $100 \mathrm{mg}$ antifoam/kg slurry) & 100.00 & $\mathrm{mg} / \mathrm{kg}$ slurry \\
\hline Number of basis antifoam additions added during SRAT cycle & 7.00 & \\
\hline Table 3 -- SME Processing Assumptions, Run \# & SB5-19 & \\
\hline Enter 1 for Redox Balance with SME Cycle or 0 for Redox Balance with no SME Cycle & 1.00 & \\
\hline Frit type & 418.00 & \\
\hline Destruction of Formic acid in SME & 5.00 & $\%$ Formate converted to $\mathrm{CO}_{2}$ etc. \\
\hline Destruction of Nitrate in SME & 0.00 & $\%$ Nitrate destroyed in SME \\
\hline Assumed SME density & 1.39 & $\mathrm{~kg} / \mathrm{L}$ \\
\hline Basis Antifoam Addition for SME cycle & 100.00 & $\mathrm{mg} / \mathrm{kg}$ slurry \\
\hline Number of basis antifoam additions added during SME cycle & 1.000 & \\
\hline Sludge Oxide Contribution in SME (Waste Loading) & 34.000 & $\%$ \\
\hline Frit Slurry Formic Acid Ratio & 0.0 & g $90 \mathrm{wt} \% \mathrm{FA} / 100 \mathrm{~g}$ Frit \\
\hline Target SME Solids total $\mathrm{Wt} \%$ & 45.0 & wt $\%$ \\
\hline Number of frit additions in SME Cycle & 2.000 & \\
\hline \# DWPF Canister decons simulated & 0.0 & \\
\hline
\end{tabular}


SRNL-STI-2008-00508, REVISION A

\begin{tabular}{|c|c|c|}
\hline & & \\
\hline \multicolumn{3}{|l|}{ Acid and Glass Calculation Base Values } \\
\hline Fresh Sludge nitrite & 2.249 & gmol \\
\hline Fresh Sludge Mn minus soluble Mn & 1.465 & gmol \\
\hline Fresh Sludge carbonate & 1.867 & gmol \\
\hline Fresh Sludge hydroxide & 9.717 & gmol \\
\hline Fresh Sludge mercury & 0.000 & gmol \\
\hline Fresh Sludge oxalate & 0.000 & gmol \\
\hline Fresh Sludge grams of calcined oxides & 1593.771 & $\mathrm{~g}$ \\
\hline Trim Chemicals Calculations & 0.0000 & \\
\hline Fresh Sludge Calcine Factor $\left(1100^{\circ} \mathrm{C}\right)$, g oxide/g dry solids (calculated) & 0.7608 & $\mathrm{~g} / \mathrm{g}$ \\
\hline Total solids before trim addition & $2,094.8625$ & $\mathrm{~g}$ \\
\hline Total solids before trim less $\mathrm{HgO}, \mathrm{NaOxalate}$, coal) & $2,094.86$ & $\mathrm{~g}$ \\
\hline Predicted total solids at target levels & $2,094.8625$ & $\mathrm{~g}$ \\
\hline Predicted total mass at target levels & $16,758.9000$ & $\mathrm{~g}$ \\
\hline Target Ag metal content in trimmed sludge & 0.000000 & total $w t \%$ dry basis \\
\hline $\mathrm{AgNO}_{3}$ to add $(\mathrm{CF}=0.682)$ & 0.00000 & $\mathrm{~g}$ \\
\hline Ag2O calcined solids & 0.00000 & $\mathrm{~g}$ \\
\hline Water added with $\mathrm{Ag}$ & 0.00000 & $\mathrm{~g}$ \\
\hline Target wt $\% \mathrm{Hg}$ dry basis & 0.000 & total $\mathrm{wt} \%$ dry basis \\
\hline Total HgO in fresh Sludge & 0.000 & $\mathrm{~g}$ \\
\hline Total $\mathrm{HgO}$ in trimmed Sludge & 0.000 & $\mathrm{~g}$ \\
\hline $\mathrm{HgO}$ to add & 0.000 & $\mathrm{~g}$ \\
\hline $\mathrm{HgO}$ calcined solids & 0.00000 & $\mathrm{~g}$ \\
\hline Water added with $\mathrm{Hg}$ & 0.00000 & $\mathrm{~g}$ \\
\hline Calculated total $\mathrm{wt} \% \mathrm{Hg}$ dry basis & 0.0000 & wt $\%$ dry basis \\
\hline Target Pd metal content in trimmed sludge & 0.0000 & total $\mathrm{wt} \%$ dry basis \\
\hline $\mathrm{Wt} \% \mathrm{Pd}$ in reagent solution & 15.2700 & wt $\%$ in solution \\
\hline $\mathrm{Pd}\left(\mathrm{NO}_{3}\right)_{2} * \mathrm{H}_{2} \mathrm{O}$ solution to add $(\mathrm{CF}=1.150 \mathrm{~g}$ metal oxide/g metal $)$ & 0.000 & $\mathrm{~g}$ of solution \\
\hline $\mathrm{Pd}(\mathrm{NO} 3) 2$ to add & 0.00000 & $\mathrm{~g}$ \\
\hline PdO calcined solids & 0.00000 & $\mathrm{~g}$ \\
\hline Water added with Pd & 0.000 & $\mathrm{~g}$ \\
\hline Target $\mathrm{Rh}$ metal content in trimmed sludge & 0.0000 & total $\mathrm{wt} \%$ dry basis \\
\hline $\mathrm{Wt} \% \mathrm{Rh}$ in reagent solution & 4.93 & wt $\%$ in solution \\
\hline $\mathrm{Rh}\left(\mathrm{NO}_{3}\right)_{3} * 2 \mathrm{H}_{2} \mathrm{O}(\mathrm{CF}=1.311 \mathrm{~g}$ metal oxide/g metal $)$ & 0.000 & g of solution \\
\hline $\mathrm{Rh}(\mathrm{NO} 3) 3$ to add & 0.00000 & $\mathrm{~g}$ \\
\hline Rh2O3 calcined solids & 0.00000 & $\mathrm{~g}$ \\
\hline Water added with $\mathrm{Rh}$ & 0.000 & $\mathrm{~g}$ \\
\hline Target Ru metal content in trimmed sludge & 0.0000 & total $\mathrm{wt} \%$ dry basis \\
\hline $\mathrm{Wt} \% \mathrm{Ru}$ in $\mathrm{RuCl}_{3}$ reagent solids & 41.74 & $w t \%$ in solids \\
\hline $\mathrm{RuCl}_{3}$ to add $(\mathrm{CF}=1.0)$ & 0.000 & g solid \\
\hline Target wt $\%$ Coal/carbon source in trimmed sludge, dry basis & 0.00 & total wt $\%$ dry basis \\
\hline Total Coal in fresh Sludge & 0.000 & $\mathrm{~g}$ \\
\hline Total Coal in trimmed Sludge & 0.000 & $\mathrm{~g}$ \\
\hline Mass of Coal to add $(\mathrm{CF}=.08)$ & 0.00 & $\mathrm{~g}$ \\
\hline Calculated wt $\%$ coal after trim additions & 0.00 & wt $\%$ \\
\hline \multicolumn{3}{|l|}{ Oxides added with coal } \\
\hline Target sodium oxalate in trimmed sludge per gm total solids & 0.00 & total $w t \%$ dry basis \\
\hline Total Sodium Oxalate in fresh Sludge & 0.000 & $\mathrm{~g}$ \\
\hline Total Sodium Oxalate in trimmed Sludge & 0.000 & $\mathrm{~g}$ \\
\hline Sodium oxalate to add $(\mathrm{CF}=0.463)$ & 0.0000000 & $\mathrm{~g}$ \\
\hline Calculated oxalate conc. after trim chemical additions & 0.00 & total $w t \%$ dry basis \\
\hline $\mathrm{Na} 2 \mathrm{O}$ calcined solids from sodium oxalate & 0.00000 & \\
\hline Total mass of trim chemicals added & 0.0 & g \\
\hline Calcined oxides added in trim chemicals & 0.00 & $\mathrm{~g}$ \\
\hline Total solids after trim addition & $2,094.86$ & g \\
\hline Match of actual to predicted total solids mass & $100.00 \%$ & \\
\hline Total Calcine solids after trim & $1,593.77$ & $\mathrm{~g}$ \\
\hline Water added to dilute and/or rinse trim chemicals & 0.0 & $\mathrm{~g}$ \\
\hline Mass of trimmed sludge & $16,758.90$ & g \\
\hline Calculated wt $\%$ total solids in trimmed sludge & 12.5 & wt $\%$ \\
\hline Sample mass of trimmed sludge & 0.00 & $\mathrm{~g}$ \\
\hline Mass of trimmed sludge reacted & $16,758.90$ & g \\
\hline Sample removal ratio at start of SRAT & 1.000 & \\
\hline Calcined solids at start of SRAT & $1,593.8$ & g \\
\hline
\end{tabular}


SRNL-STI-2008-00508, REVISION A

\begin{tabular}{|c|c|c|}
\hline \multicolumn{3}{|l|}{ STOICHIOMETRIC ACID CALCULATION } \\
\hline \multicolumn{3}{|l|}{ Stoichiometric Acid Ratios Used } \\
\hline Acid requirement per mole of Nitrite & 0.75 & mole $\mathrm{H}+/$ mole NO2- \\
\hline Acid requirement per mole of $\mathrm{Mn}$ & 1.20 & mole $\mathrm{H}+/$ mole $\mathrm{Mn}$ \\
\hline Acid requirement per mole of Carbonate & 2.00 & mole $\mathrm{H}+/$ mole $\mathrm{CO} 3=$ \\
\hline Acid requirement per mole of Hydroxide & 1.00 & mole $\mathrm{H}+/$ mole OH- \\
\hline Acid requirement per mole of $\mathrm{Hg}$ & 1.00 & mole $\mathrm{H}+/$ mole $\mathrm{Hg}++$ \\
\hline Acid requirement per mole of Oxalate & 0.00 & mole $\mathrm{H}+/$ mole $\mathrm{C} 2 \mathrm{O} 4=$ \\
\hline Fresh feed $\mathrm{NO}_{2}^{-}$ & 1.6871 & gmol \\
\hline Fresh feed Mn & 1.75803 & gmol \\
\hline Fresh feed Carbonate & 3.7339 & gmol \\
\hline Fresh feed $\mathrm{OH}^{-}$ & 9.7171 & gmol \\
\hline $\mathrm{Hg}$ from trim & 0.000000 & gmol \\
\hline Hg from fresh sludge & 0.00000 & gmol \\
\hline Total Stoichiometric Acid required & 16.8961 & gmol \\
\hline Percent Acid in Excess Stoichiometric Ratio & 130.000 & $\%$ \\
\hline Actual acid to add to SRAT & 21.9649 & gmol \\
\hline Acid required in moles per liter of starting sludge (less receipt samples) & 1.4286 & gmol/L \\
\hline \multicolumn{3}{|l|}{ REDOX CALCULATION (SME PRODUCT REDOX PREDICTION) } \\
\hline REDOX Target & 0.200 & $\mathrm{Fe}+2 / \mathrm{Fe}$ \\
\hline Predicted REDOX & 0.200 & \\
\hline Ratio of formic acid to total acid & 0.8425 & moles formic acid / mole total acid \\
\hline Delta between predicted REDOX and target REDOX & -0.000002 & \\
\hline Activation of SME cycle corrections? (1=SME corrections performed): & 1 & \\
\hline Nitric acid density, $20^{\circ} \mathrm{C}$ & 1.308 & $\mathrm{~g} / \mathrm{mL}$ \\
\hline Formic acid density, $20^{\circ} \mathrm{C}$ & 1.2047 & $\mathrm{~g} / \mathrm{mL}$ \\
\hline Nitric acid, wt \% & 49.80 & wt \% \\
\hline Formic acid, wt \% & 90.16 & wt \% \\
\hline Formic acid amount & 18.506 & gmol \\
\hline Nitric acid amount & 3.459 & gmol \\
\hline Total Manganese in fresh feed & 1.465 & gmol \\
\hline Manganese removed with SRAT product sample & 0.000 & gmol \\
\hline Projected Melter Feed Manganese, total moles & 1.465 & gmol \\
\hline Formate moles with fresh sludge & 0.000 & gmol \\
\hline Formate moles added with formic acid & 18.506 & gmol \\
\hline Formate moles destroyed in SRAT ( $\%$ of acid charged) & 2.776 & gmol \\
\hline Formate moles removed with SRAT product sample & 0.000 & gmol \\
\hline Formate moles reacted in SME ( $\%$ of acid charged) & 0.787 & gmol \\
\hline Formate Moles after SME & 14.944 & gmol \\
\hline Frit slurry formate (when SME cycle frit additions are made with formic acid) & 0.000 & gmol \\
\hline Projected Melter Feed Formate, total moles & 14.944 & gmol \\
\hline Nitrate moles from fresh sludge & 1.065 & gmol \\
\hline Nitrate moles from nitric acid & 3.459 & gmol \\
\hline Nitrate from conversion of nitrite to nitrate in SRAT and SME & 0.450 & gmol \\
\hline Nitrate from minor trim chemicals & 0.00000 & gmol \\
\hline Nitrate removed with SRAT product sample & 0.00000 & gmol \\
\hline Nitrate destroyed in the SME & 0.00000 & gmol \\
\hline Projected Melter Feed Nitrate, total moles (Sum of inputs - destroyed) & 4.974 & gmol \\
\hline Oxalate in fresh feed & 0.000 & gmol \\
\hline Oxalate from trim & 0.000 & gmol \\
\hline Oxalate destroyed during reaction & 0.000 & gmol \\
\hline Oxalate removed with SRAT product sample & 0.000 & gmol \\
\hline Projected Melter Feed Oxalate, total moles & 0.000 & gmol \\
\hline Carbon from Coal in fresh feed & 0.000 & gmol \\
\hline Carbon from trim coal & 0.000 & gmol \\
\hline Carbon removed in SRAT product Sample & 0.000 & gmol \\
\hline Projected Melter Feed Carbon from coal, total moles & 0.000 & gmol \\
\hline Projected Melter Feed Nitrite, total moles & 0.0000 & gmol \\
\hline Assumed SME density & 1.390 & $\mathrm{~g} / \mathrm{ml}$ \\
\hline Projected final SME mass & 12.876 & $\mathrm{~kg}$ \\
\hline Manganese concentration in final melter feed & 0.114 & gmol/kg melter feed slurry \\
\hline Formate concentration in final melter feed & 1.161 & gmol $/ \mathrm{kg}$ melter feed slurry \\
\hline Oxalate concentration in final melter feed & 0.000 & gmol/kg melter feed slurry \\
\hline Carbon from coal concentration in final melter feed & 0.000 & gmol $/ \mathrm{kg}$ melter feed slurry \\
\hline Nitrate concentration in final melter feed & 0.386 & gmol $/ \mathrm{kg}$ melter feed slurry \\
\hline Nitrite concentration in final melter feed & 0.000 & gmol $/ \mathrm{kg}$ melter feed slurry \\
\hline
\end{tabular}


SRNL-STI-2008-00508, REVISION A

\begin{tabular}{|c|c|c|}
\hline \multicolumn{3}{|l|}{ BENCH SCALE CALCULATIONS } \\
\hline \multicolumn{3}{|l|}{ Bench Scale Operational Setting } \\
\hline Scaled formic acid feed rate based on nominal $23.551 \mathrm{M}$ & 5.1139 & $\mathrm{ml} / \mathrm{min}$ \\
\hline Scaled nitric acid feed rate based on nominal $10.395 \mathrm{M}$ & 5.1517 & $\mathrm{ml} / \mathrm{min}$ \\
\hline Prototypical formic acid feed time & 153.3 & $\min$ \\
\hline Prototypical nitric acid feed time & 64.9 & $\min$ \\
\hline Formic acid volume required & 784.156 & $\mathrm{ml}$ \\
\hline Nitric acid volume required & 334.511 & $\mathrm{ml}$ \\
\hline $\mathrm{Wt} \%$ active agent in antifoam solution & 10 & $\%$ \\
\hline Target concentration for overall SRAT cycle & 700 & ppm \\
\hline Total SRAT antifoam charge for 1:10 dilution & 117.31 & $\mathrm{~g}$ \\
\hline $100 \mathrm{ppm}$ SRAT antifoam charge at 1:10 & 16.76 & $\mathrm{~g}$ \\
\hline \multicolumn{3}{|l|}{ Dewatering Calc for Target Wt. \% Total Solids in SRAT Product } \\
\hline \begin{tabular}{|l} 
Final SRAT Product Total Solids (UNDER TOOLS USE SOLVER) \\
\end{tabular} & 25.00 & $\%$ \\
\hline Water in Trimmed (and sampled) Sludge & $14,664.04$ & $\mathrm{~g}$ \\
\hline Water added with antifoam & 222.89 & $\mathrm{~g}$ \\
\hline Water added with formic acid & 92.93 & $\mathrm{~g}$ \\
\hline Water added with nitric acid & 219.73 & $\mathrm{~g}$ \\
\hline Water added in acid flushing & 50.00 & $\mathrm{~g}$ \\
\hline Water made during base equiv neutralization & 175.06 & $\mathrm{~g}$ \\
\hline Water made in TIC destruction & 33.63 & $\mathrm{~g}$ \\
\hline Water made in SRAT nitrite destruction & 13.51 & $\mathrm{~g}$ \\
\hline Water made in Mercury Reduction & 0.00 & \\
\hline Revised water mass in slurry & $15,471.79$ & $\mathrm{~g}$ \\
\hline Solids in Trimmed (and sampled) Sludge & $2,094.86$ & $\mathrm{~g}$ \\
\hline Mass 1:20 antifoam added & 11.73 & $\mathrm{~g}$ \\
\hline Mass of pure formic acid $(\mathrm{HCOOH})$ added & 851.75 & $\mathrm{~g}$ \\
\hline Mass of pure nitric acid (HNO3) added & 217.95 & $\mathrm{~g}$ \\
\hline Solids lost during base equiv neutralization & 175.06 & $\mathrm{~g}$ \\
\hline Solids lost in TIC destruction & 115.80 & $\mathrm{~g}$ \\
\hline Solids lost in SRAT nitrite destruction & 58.51 & $\mathrm{~g}$ \\
\hline Solids lost in SRAT nitrite destruction & 76.50 & $\mathrm{~g}$ \\
\hline Solids lost in SRAT formate destruction (formic acid) & 127.76 & $\mathrm{~g}$ \\
\hline Solids lost in Mercury Stripping & 0.00 & \\
\hline Revised solids mass in slurry & $2,699.17$ & $\mathrm{~g}$ \\
\hline Target final water mass in slurry to hit total solids target & $8,097.52$ & $\mathrm{~g}$ \\
\hline Total water to remove & $7,374.27$ & $\mathrm{~g}$ \\
\hline Calculated total water to remove to return to starting volume & $1,613.76$ & $\mathrm{~g}$ \\
\hline net (used in Macro iteration) & -5760.52 & $\mathrm{~g}$ \\
\hline Mass of carbonate lost as $\mathrm{CO}_{2}$ & 82.16 & $\mathrm{~g}$ \\
\hline Mass of nitrite lost as NO & 36.00 & $\mathrm{~g}$ \\
\hline Formate converted to $\mathrm{CO}_{2}$ & 127.76 & $\mathrm{~g}$ \\
\hline Formate converted to $\mathrm{CO} 2$ in SRAT & 127.76 & $\mathrm{~g}$ \\
\hline Final sludge mass in SRAT after acid addition and dewater (neglecting samples) & 10796.69 & $\mathrm{~g}$ \\
\hline Mass of SRAT cycle samples (excluding SRAT Receipt) & 0.00 & $\mathrm{~g}$ \\
\hline Mass of treated sludge going into SME cycle & 10796.69 & $\mathrm{~g}$ \\
\hline SME sample ratio & 1.0000 & \\
\hline Calcined Solids going to SME & 1593.77 & $\mathrm{~g}$ \\
\hline
\end{tabular}


SRNL-STI-2008-00508, REVISION A

\begin{tabular}{|c|c|c|}
\hline \multicolumn{3}{|l|}{ DWPF SCALE TO BENCH SCALE } \\
\hline DWPF Scale SRAT cycle & & \\
\hline density estimate $=$ & 1.090 & \\
\hline Volume based scale factor 6000 gal starting SRAT & 1477.2 & \\
\hline SRAT air purge & 230 & scfm \\
\hline SRAT boil-up rate & 5000 & lbs/hr \\
\hline SRAT total boil-up (reflux) & 60,000 & lbs \\
\hline Indicated SRAT refluxing time & 720 & $\min$ \\
\hline \multicolumn{3}{|l|}{ Bench Scale SRAT cycle } \\
\hline $99.5 \%$ of scaled air purge & 4386.8 & sccm \\
\hline Helium purge rate at $0.5 \mathrm{vol} \%$ & 21.9 & sccm \\
\hline Scaled boil-up rate & 25.59 & $\mathrm{~g} / \mathrm{min}$ \\
\hline Required dewatering time at above rate & 288.2 & $\min$ \\
\hline \multicolumn{3}{|l|}{ DWPF Scale SME cycle } \\
\hline Water flush volume after frit slurry addition & 0.0 & gal \\
\hline SME air purge & 74.0 & scfm \\
\hline SME boil-up rate & 5000 & lbs/hr \\
\hline \multicolumn{3}{|l|}{ Bench Scale SME cycle } \\
\hline SME scale factor (ADJUSTED FOR SRAT SAMPLES) & 1477.2 & \\
\hline $99.5 \%$ scaled SME air purge & 1411.4 & sccm \\
\hline Helium purge rate at $0.5 \mathrm{vol} \%$ & 7.06 & sccm \\
\hline Solids remaining at start of SME & 2699.2 & g \\
\hline SRAT product Calcine Factor (calculated) & 0.590 & g oxide/g dry SRAT Product \\
\hline Sludge calcined solids - based on SRAT product & 1593.77 & g \\
\hline Sludge oxide contribution in SME & 34.00 & $\%$ \\
\hline Frit oxide contribution & 66.00 & $\%$ \\
\hline Frit slurry wt \% solids & 50.00 & wt $\%$ \\
\hline Frit slurry formic acid ratio & 0.00 & g $90 \mathrm{wt} \% \mathrm{FA} / 100$ g Frit \\
\hline Added water simulating decontamination of canisters & 0.0 & g \\
\hline SME cycle antifoam addition at $1: 10$ & 10.80 & $\mathrm{~g}$ \\
\hline Frit solids (total) & 3093.8 & g \\
\hline $90 \mathrm{wt} \%$ formic acid (corrections necessary for other concentrations) & 0.00 & $\mathrm{~g}$ \\
\hline Water in frit slurry & 3093.8 & $\mathrm{~g}$ \\
\hline Scaled transfer water & 0.00 & $\mathrm{~g}$ \\
\hline Total frit slurry water & 3093.8 & $\mathrm{~g}$ \\
\hline Total mass of frit slurry & 6187.6 & $\mathrm{~g}$ \\
\hline Number of equal SME frit slurry additions & 2 & \\
\hline Each SME frit addition & 1546.9 & $\mathrm{~g}$ \\
\hline Each SME 90-wt $\%$ formic acid addition & 0.00 & $\mathrm{~g}$ \\
\hline Each SME water addition & 1546.9 & $\mathrm{~g}$ \\
\hline Scaled SME boil-up rate & 25.59 & $\mathrm{~g} / \mathrm{min}$ \\
\hline Approximate time to remove water: & 60.5 & $\min$ \\
\hline \begin{tabular}{|l} 
Final solids content in SME \\
\end{tabular} & 5794.0 & $\mathrm{~g}$ \\
\hline Target SME solids total wt $\%$ & 45.0 & $\%$ \\
\hline Mass of water to boil off for final SME concentration & 1036.4 & $\mathrm{~g}$ \\
\hline Scaled boil-up rate & 25.59 & $\mathrm{~g} / \mathrm{min}$ \\
\hline Approximate time to reach solids target concentration. & 40.5 & $\min$ \\
\hline
\end{tabular}


SRNL-STI-2008-00508, REVISION A

\section{APPENDIX B. SMRF Glass Analysis (wt\% Oxide)}

\begin{tabular}{|c|c|c|c|c|c|c|c|c|c|c|c|}
\hline Sample ID & $\mathbf{A l}_{2} \mathbf{O}_{3}$ & $\mathbf{B}_{2} \mathbf{O}_{3}$ & $\mathrm{BaO}$ & $\mathrm{CaO}$ & $\mathrm{CeO}_{2}$ & $\mathrm{Cr}_{2} \mathrm{O}_{3}$ & $\mathrm{CuO}$ & $\mathrm{Fe}_{2} \mathrm{O}_{3}$ & $\mathbf{K}_{2} \mathbf{O}$ & $\mathbf{L i}_{2} \mathbf{O}$ & MgO \\
\hline SMRF 0234 (A) & 9.56 & 5.31 & 0.025 & 0.937 & 0.047 & 0.050 & 0.030 & 11.3 & 0.184 & 4.75 & 0.911 \\
\hline SMRF 0234 (B) & 9.60 & 5.28 & 0.025 & 0.939 & 0.047 & 0.053 & 0.023 & 11.3 & 0.185 & 4.71 & 0.908 \\
\hline SMRF 0236 (A) & 8.83 & 5.02 & 0.015 & 0.875 & 0.02 & 0.039 & 0.03 & 11.1 & 0.125 & 4.69 & 0.739 \\
\hline SMRF 0236 (B) & 8.94 & 4.96 & 0.015 & 0.889 & 0.02 & 0.034 & 0.03 & 11.1 & 0.120 & 4.71 & 0.754 \\
\hline SMRF 0237(A) & 8.49 & 6.70 & $<0.011$ & 0.869 & 0.012 & 0.047 & 0.028 & 10.9 & 0.097 & 5.05 & 0.702 \\
\hline SMRF 0237 (B) & 8.51 & 6.44 & $<0.011$ & 0.858 & 0.012 & 0.047 & 0.026 & 10.9 & 0.103 & 4.92 & 0.689 \\
\hline SMRF 0238 (A) & 8.16 & 7.28 & $<0.011$ & 0.812 & $<.012$ & 0.140 & 0.020 & 11.0 & 0.094 & 5.10 & 0.634 \\
\hline SMRF 0238 (B) & 8.22 & 7.34 & $<0.011$ & 0.825 & $<.012$ & 0.145 & 0.023 & 11.1 & 0.092 & 5.14 & 0.637 \\
\hline Sample ID & $\mathrm{MnO}_{2}$ & $\mathrm{Na}_{2} \mathrm{O}$ & NiO & $\mathbf{P}_{2} \mathbf{O}_{5}$ & PbO & $\mathrm{SO}_{4}$ & $\mathrm{SiO}_{2}$ & $\mathrm{TiO}_{2}$ & $\mathrm{ZnO}$ & $\mathrm{ZrO}_{2}$ & Total \\
\hline SMRF 0234 (A) & 2.88 & 12.8 & 0.841 & $<.229$ & $<.011$ & 0.363 & 50.5 & 0.097 & 0.030 & 0.128 & 101 \\
\hline SMRF 0234 (B) & 2.88 & 12.8 & 0.847 & $<.229$ & $<.011$ & 0.360 & 50.7 & 0.100 & 0.025 & 0.132 & 101 \\
\hline SMRF 0236 (A) & 2.83 & 13.1 & 1.02 & $<.229$ & $<.011$ & 0.258 & 50.5 & 0.085 & 0.024 & 0.126 & 99.4 \\
\hline SMRF 0236 (B) & 2.97 & 13.2 & 1.05 & $<.229$ & $<.011$ & 0.258 & 50.7 & 0.089 & 0.021 & 0.128 & 100 \\
\hline SMRF 0237(A) & 2.97 & 13.5 & 1.14 & $<.229$ & $<.011$ & 0.303 & 50.9 & 0.055 & 0 & 0.069 & 102 \\
\hline SMRF 0237 (B) & 2.99 & 13.5 & 1.13 & $<.229$ & $<.011$ & 0.300 & 51.1 & 0.053 & 0 & 0.070 & 102 \\
\hline SMRF $0238(\mathrm{~A})$ & 2.88 & 13.2 & 1.31 & $<.229$ & $<.011$ & 0.210 & 49.2 & 0.035 & 0 & 0.027 & 100 \\
\hline SMRF 0238 (B) & 2.91 & 13.2 & 1.36 & $<.229$ & $<.011$ & 0.210 & 49.4 & 0.025 & 0 & 0.024 & 101 \\
\hline & & & & & & & & & & & \\
\hline
\end{tabular}


APPENDIX C. SMRF REDOX Results

\begin{tabular}{|c|c|c|c|c|c|c|}
\hline & & & & & $\mathrm{Fe}(2+)$ & $\overline{\mathrm{Fe}(2+)}$ \\
\hline Sample & Lab ID & $\underline{\mathrm{Fe}(2+)}$ & $\mathrm{Fe}(3+)$ & Fe(total) & $\mathbf{F e}(3+)$ & Fe(total) \\
\hline EA & & 0.050 & 0.187 & 0.237 & 0.267 & 0.211 \\
\hline 19/20 BLEND-1 (A) & 08-2297 & 0.025 & 0.150 & 0.175 & 0.167 & 0.143 \\
\hline 19/20 BLEND-1 (B) & 08-2297 & 0.025 & 0.151 & 0.176 & 0.166 & 0.142 \\
\hline 19/20 BLEND-2 (A) & 08-2298 & 0.034 & 0.208 & 0.242 & 0.163 & 0.140 \\
\hline 19/20 BLEND-2 (B) & 08-2298 & 0.034 & 0.209 & 0.243 & 0.163 & 0.140 \\
\hline 19/20 BLEND-3 (A) & 08-2299 & 0.030 & 0.175 & 0.205 & 0.171 & 0.146 \\
\hline 19/20 BLEND-3 (B) & 08-2299 & 0.030 & 0.175 & 0.205 & 0.171 & 0.146 \\
\hline 21/22 BLEND-1 (A) & 08-2300 & 0.023 & 0.127 & 0.150 & 0.181 & 0.153 \\
\hline 21/22 BLEND-1 (B) & $08-2300$ & 0.024 & 0.126 & 0.150 & 0.190 & 0.160 \\
\hline 21/22 BLEND-2 (A) & $08-2301$ & 0.032 & 0.181 & 0.213 & 0.177 & 0.150 \\
\hline 21/22 BLEND-2 (B) & $08-2301$ & 0.031 & 0.182 & 0.213 & 0.170 & 0.146 \\
\hline 21/22 BLEND-3 (A) & 08-2302 & 0.029 & 0.192 & 0.221 & 0.151 & 0.131 \\
\hline 21/22 BLEND-3 (B) & 08-2302 & 0.030 & 0.193 & 0.223 & 0.155 & 0.135 \\
\hline
\end{tabular}




\section{Distribution:}

J. C. Griffin, 773-A

S. L. Marra, 773-A

A. B. Barnes, 999-W

D. A. Crowley, 773-43A

S. D. Fink, 773-A

C. W. Gardner, 773-A

B. J. Giddings, 786-5A

C. C. Herman, 999-W

F. M. Pennebaker, 773-42A

J. E. Occhipinti, 704-S

D. C. Sherburne, 704-S

R. T. McNew, 704-27S

J. F. Iaukea, 704-30S

J. W. Ray, 704-S

H. B. Shah, 766-H

J. M. Gillam, 766-H

B. A. Hamm, 766-H

D. D. Larsen, 766-H

C. J. Bannochie, 773-42A

A. Y. Billings, 999-W

A. S. Choi, 773-42A

K. M. Fox, 999-W

D. J. McCabe, 773-42A

D. H. Miller, 999-W

J. D. Newell, 999-W

D. K. Peeler, 999-W

B. R. Pickenheim, 999-W

F. C. Raszewski, 999-W

M. E. Stone, 999-W

J. P. Vaughan, 773-41A

P. L. Bovan, 704-27S

M. A. Broome, 704-29S

A. J. Cross, 704-71S

J. M. Bricker, 704-27S

T. L. Fellinger, 704-26S

E. W. Holtzscheiter, 704-15S

M. T. Keefer, 766-H

M. E. Smith, 704-30S 